\title{
EDITORIAL
}

\section{The challenge of change}

This year South Africa celebrates 20 years of democracy. The anniversary, coming in an election year, provides an opportunity for the ANC government to reflect back on the achievements of the past 20 years. Equally, opposition parties will seize the moment to reflect on the failures of the past 20 years. These analyses, and the accompanying array of somewhat baffling statistics, ${ }^{1}$ focus - for good reason on what the government has or has not done to improve conditions for its citizens. Excluded from these analyses are reflections on the role played by the multitude of non-governmental organisations that continue to support the implementation of legislation and offer a wide range of services at community level under difficult and uncertain circumstances.

The jury is still out on how useful it is to gaze back at each decade post-apartheid and count our successes and failures. It is certainly not clear that it serves any purpose other than providing politicians with a framework within which to promote their interests. As such, I shall resist the temptation to reiterate here the claims already made about changes, or lack thereof, to the criminal justice system. However, our next edition - SACQ 48 - will be a special edition dedicated to assessing the impact of policy changes on access to justice, effective policing, violence prevention and incarceration in South Africa over the past 20 years.

In this edition of SACQ Stacy Moreland starts the process of assessing transformation, or rather the lack thereof, by offering an analysis of judgements made in rape cases in the Western Cape. She comes to the rather depressing, but perhaps quite predictable finding that patriarchal notions of gender still inform judgements in rape cases - and in so doing reinforce stereotypical ideas of worthy and unworthy victims.

Staying with the adjudication of rape cases, Heidi Barnes offers an analysis of the Constitutional Court case Fv Minister of Safety and Security in which the Court established the basis for determining the vicarious responsibility of the state, in this case for the criminal act of a police officer. The case in question involved the rape of a young woman by a police officer who was on standby duty. Barnes argues that this case 'has at last provided clarity and transparency on the normative bases for holding the state vicariously liable for the criminal acts of police officers. These are the police's constitutional obligations to protect the public, and the entitlement of the public to place their trust in the police.' The ruling, she argues, significantly increases the likelihood of the Minister of Police being held responsible for criminal acts conducted by the police, even those who are not on duty at the time of the act.

In their article, Alexandra Hiropoulos and Jeremy Porter of the City University of New York (CUNY) demonstrate how Geographic Information Systems (GIS) can be used, along with crime pattern theory, to analyse police crime data. They argue that this method of crime analysis could offer the police and local government important insights into the geography of crime. However, there are still huge gaps in publicly available data that at present complicate and reduce the utility of these kinds of analyses in South Africa. This may change over time, and would certainly be helped if the SAPS were to release more detailed crime statistics more often and if there were to be a better overlap between the different geographic units of analysis (e.g. police precincts and municipal wards). However, the article also suggests that there may be a danger in presuming that new high-tech software and systems can 
necessarily tell us more than we already know, or than we can learn from more traditional forms of analysis.

Geoff Harris, Crispin Hemson and Sylvia Kaye report on a conference held in Durban in mid-2013 on measures to reduce violence in schools. According to the 2012 National School Violence Study ${ }^{2}$ by the Centre for Justice and Crime Prevention, violence in South African schools has remained at stubbornly high levels over the past five years. This conference highlighted the enormous challenges faced by learners who have to deal with the persistent reliance of teachers on harsh corporal punishment as well as violence between learners, particularly aimed at learners who don't conform to heteronormative gender stereotypes. While it is easy to become overwhelmed by the scale of the problem, the conference also showcased the work of a significant number of civil society interventions to prevent and reduce violence, and support learners. Given the evidence presented about the effectiveness of many of the violence reduction initiatives undertaken by NGOs and academics, one has to wonder whether we might not have made greater strides in reducing violence nationally if there were a concerted effort to ensure the sustainability and scaleability of these activities.

We end this edition with a review by Hema Hargovan of the latest edition of Victimology in South Africa by Robert Peacock (ed).

This year the Governance, Justice and Crime Division of the ISS will hold its fifth International Conference on Crime Reduction and Criminal Justice. The call for abstracts was announced at the beginning of March. The conference will be held in Johannesburg during the second week of August. Applications have also opened for the second African Publication Mentoring Programme offered by the ISS, with the first meeting of mentors and mentees taking place the day before the conference. Details of both the mentoring programme and the conference are available from the ISS website (www.issafrica.org).

\section{Chandré Gould (Editor)}

\section{NOTES}

1. For a particularly good example of the presentation of baffling statistics see 'Twenty year review of criminal justice', statement launched at a post-State of the Nation media briefing by the JCPS cluster, Cape Town: 12 March 2014.

2. Patrick Burton and Lezanne Leoschut, School violence in South Africa: results of the 2012 National School Violence Study, Cape Town: Centre for Justice and Crime Prevention, 2013.

\section{Editorial policy}

South African Crime Quarterly is an inter-disciplinary peer-reviewed journal that promotes professional discourse and the publication of research on the subjects of crime, criminal justice, crime prevention, and related matters, including state and non-state responses to crime and violence. South Africa is the primary focus for the journal but articles on the above-mentioned subjects that reflect research and analysis from other African countries are considered for publication, if they are of relevance to South Africa.

SACQ is an applied policy journal. Its audience includes policy makers, criminal justice practitioners and civil society researchers and analysts, including the academy. The purpose of the journal is to inform and influence policy making on violence prevention, crime reduction and criminal justice. All articles submitted to SACQ are double-blind peer-reviewed before publication. 